Alexander Soifer

\title{
How Does One \\ Cut a Triangle?
}

\section{Second Edition}

Forewords by

Philip L. Engel

Paul Erdós

Branko Grünbaum

Peter D. Johnson, Jr.

and Cecil Rousseau

脰 Springer 


\section{Contents}

Forewords for the Second Edition

Foreword by Branko Grünbaum $\ldots \ldots \ldots \ldots \ldots \ldots \ldots$ ix

Foreword by Peter D. Johnson, Jr. ............. $\quad x$

Forewords for the First Edition

Foreword by Philip L. Engel $\ldots \ldots \ldots \ldots \ldots \ldots \ldots \ldots$ xiii

Foreword by Paul Erdős $\ldots \ldots \ldots \ldots \ldots \ldots \ldots \ldots \ldots$ xiv

Foreword by Branko Grünbaum $\ldots \ldots \ldots \ldots \ldots \ldots \ldots \ldots \ldots \ldots \ldots \ldots \ldots$

Foreword by Cecil Rousseau $\ldots \ldots \ldots \ldots \ldots \ldots \ldots \ldots$ xvi

Preface to the Second Edition $\ldots \ldots \ldots \ldots \ldots \ldots \ldots \ldots \ldots$, xxi

Preface to the First Edition $\ldots \ldots \ldots \ldots \ldots \ldots \ldots \ldots \ldots$ xxvii

\section{Part I The Original Book}

1 A Pool Table, Irrational Numbers, and

Integral Independence $\ldots \ldots \ldots \ldots \ldots \ldots \ldots \ldots \ldots, \quad 3$

1.1 A Pool Table Problem .................... 3

1.2 Numbers Rational and Irrational ............. 7

1.3 Integral Independence $\ldots \ldots \ldots \ldots \ldots \ldots \ldots \ldots . \quad 8$

2 How Does One Cut a Triangle? I .............. 15 
xviii Contents

3 Excursions in Algebra $\ldots \ldots \ldots \ldots \ldots \ldots \ldots \ldots \ldots, 25$

3.1 A Good Try ......................... 25

3.2 Excursion in Linear Algebra ................ 27

3.3 Excursion in Algebraic Equations ............ 34

4 How Does One Cut a Triangle? II ............. 37

$5 \quad$ Excursion in Trigonometry $\ldots \ldots \ldots \ldots \ldots \ldots \ldots \ldots, 41$

6 Is There Anything Beyond the Solution? .......... 47

$7 \quad$ Pursuit of the Best Result................... 51

7.1 Birth of a Problem ..................... 51

7.2 The Optimal Result .................... 55

7.3 Second Solution to the Five-Point Problem ........ 60

8 Convex Figures and the Function $S(F) \ldots \ldots \ldots \ldots 6$

8.1 Creating a Function ...................... 65

8.2 Study of Convex Figures:

The Upper Bound of $\mathbf{S}(F) \ldots \ldots \ldots \ldots \ldots \ldots \ldots$

8.3 Study of Convex Figures:

A Lower Bound of $\mathbf{S}(F) \ldots \ldots \ldots \ldots \ldots \ldots \ldots, 77$

8.4 A Very Brief Introduction to

Affine Geometry ........................ 79

8.5 Study of Convex Figures:

The Best Lower Bound of $\mathbf{S}(F) \ldots \ldots \ldots \ldots \ldots . \quad 86$

8.6 A One-Hundred-Dollar Problem .............. 96

8.7 Triangle in Ellipse..................... 99

9 Paul Erdős: Our Joint Problems .................. 107

9.1 PGOM Erdős ............................. 107

9.2 Problems................................. 109

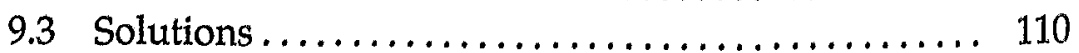

10 Convex Figures and Erdốs $s^{\prime}$ Function $S_{\alpha}(F) \ldots \ldots \ldots 121$ 
Part II Developments of the Subsequent 20 Years

11 An Alternative Proof of Grand Problem II .......... 127

12 Miklós Laczkovich on Cutting Triangles ........... 129

13 Matthew Kahle on the Five-Point Problem ........ 137

14 Soifer's One-Hundred-Dollar Problem and Mitya Karabash ....................... 143

15 Coffee Hour and the Conway-Soifer Cover-Up ...... 147

16 Farewell to the Reader................... 157

Appendix A Cutting a Triangle into Congruent Triangles. 161 Appendix B The Five-Point Problem .............. 163

References ............................. 167

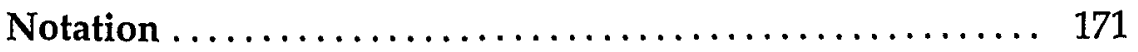

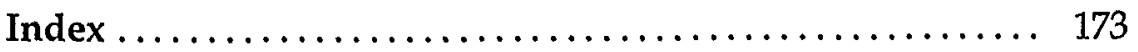

